\title{
The Urgency of HOTS-Oriented Learning and Assessment Towards Quality of Education in Facing Indonesia Sustainable Development Goals (SDGs) 2030:
}

\author{
A Literature Review
}

\author{
Suhendro* \\ School of Postgraduate, Department of Geography \\ Education \\ Universitas Pendidikan Indonesia \\ Bandung, Indonesia \\ *suhendrogeografi11@gmail.com
}

\author{
Dede Sugandi, Mamat Ruhimat \\ Geography Education Postgraduate Lecturer \\ Universitas Pendidikan Indonesia \\ Bandung, Indonesia
}

\begin{abstract}
In the early decades of the 21st century, especially in the era of industrial revolution 4.0, there are many demands on human resources quality improvement in the field of education. One of the ways to meet the demands is through learning process and classroom assessment. Nowadays, people are discussing and developing high-level order thinking skills (HOTS) oriented learning and assessment in order to increase the quality of education in Indonesia. Basically, the education quality is one indicator of sustainable development goals (SGDs) 2030. Therefore, this study aimed at investigating 1) Urgency of HOTSoriented learning towards the quality of education in facing Indonesia SDGs 2030. 2) Urgency of HOTS-oriented assessment towards the quality of education in facing Indonesia SDGs 2030. The method used in this study is literature review by using descriptive qualitative approach, and the data were collected from various relevant references consist of indexed journals, books and other types of sources. The findings of this study prove that 1) The implementation of HOTS-oriented learning during teaching and learning in the classroom is important to improve the quality of education, and 2) The implementation of HOTSoriented assessment in classroom learning is significant in order to improve the education quality in Indonesia to face Indonesia Sustainable Development Goals (SDGs) 2030. In conclusion, the implementation of HOTS learning and assessment in the classroom is very vital in order to improve the quality of Indonesian human resources in facing the Indonesia Sustainable Development Goals (SDGs) 2030 specifically in the field of education.
\end{abstract}

Keywords-learning, assessment, HOTS, Indonesia's Sustainable Development Goals (SGDs)

\section{INTRODUCTION}

Currently the education system has been designed on academic ideas and professional abilities that are in line with the dictates of the industrial revolution [1][2]. The $21^{\text {st }}$ century industry will gradually depend on the generation of knowledge through creativity and innovation [3][4]. The rapid development of times and globalization demands a rise within the education quality. Every education system must be ready to make changes concerning an improved and better quality [5]. Directing education into the future, the turn of the century finds the education of stakeholders involved in controversial discussions about which skills and competencies should guide policy and $21^{\text {st }}$ century educational practice [2] because education can change values, attitudes, skills and behavior especially through a broad and deep understanding of sustainable development issues [6][7][8].

The conditions continue to change afterward. Competitive market reglations connected to the global political, social and economic systems have led to an immense growth in the knowledge generation, industrial management, and information communication technology (ICT). This condition has great effects on institutional education, changes the conditions for policymakers and educators and challenges taken concepts such as knowledge, information and abilities [9]. In this condition, the $21^{\text {st }}$ century led to a new approach to the important given skills for students in order to experience academic and life success [2].

One of those approaches to academic success is by using HOTS approach. This approach can be implemented during learning and classroom assessments. HOTS is an ability that students in the $21^{\text {st }}$ century must have [2][10][11]. This highlevel thinking ability can be mastered by students if students grasp and integrate their knowledge with the experiences they have [12]. Efforts to improve higher-order thinking skills are not only focused on student activities but are also influenced by 
the strategies used by the teacher during the learning process [13][14][15][16]. This strategy aims to link students' thinking skills during the learning process in the classroom.

Today, high-order thinking skills become a hot issue in the education system in Indonesia. Basically, the ability to think at a higher level is an ability that trains students to get used in dealing with problems in the real world. In this level of thinking, students are not only required to think critically but also to be creative in solving problems [17]. These high-order thinking skills can also make students develop their careers, have more achievements, have social skills, have self-control, be creative, be responsible, work hard, and be able to solve problems by making the right decisions [18].

Higher order thinking skills are an educational challenge in the twenty-first century. To improve the quality of education, especially in the $21^{\text {st }}$ Century, students need to develop higherorder thinking skills. Higher order thinking skills can also be trained and developed through classroom learning [19]. Craig [20] suggests that in the $21^{\text {st }}$ century students will deal with unusual problems, so they must be familiar with activities related to solution to problem. In this case, problem solving can be solved through the ability to analyze, evaluate, and create, where the three components of these abilities are included in the high order realm of thinking abilities. Therefore, higher order thinking skills are important things that must be possessed by students in the $21^{\text {st }}$ century.

Recently, the Program for International Student Assessment (PISA) released the results of the 2018 PISA survey, placing Indonesia in $74^{\text {th }}$ place, which is the sixth from the bottom. In the Science category, Indonesia scored 396, far below the OECD average score of 489. Meanwhile, in Mathematics, Indonesia is ranked $7^{\text {th }}$ from the bottom with a score of 379 (OECD average of 489). Meanwhile, the lowest score obtained by Indonesia was in the Reading category, namely 371 (OECD average of 489). The following is a comparison of the results of PISA data of Indonesia and several countries based on Reading Performance, Mathematics Performance and Science Performance, which is presented in Figure 1, 2, 3 as follows:

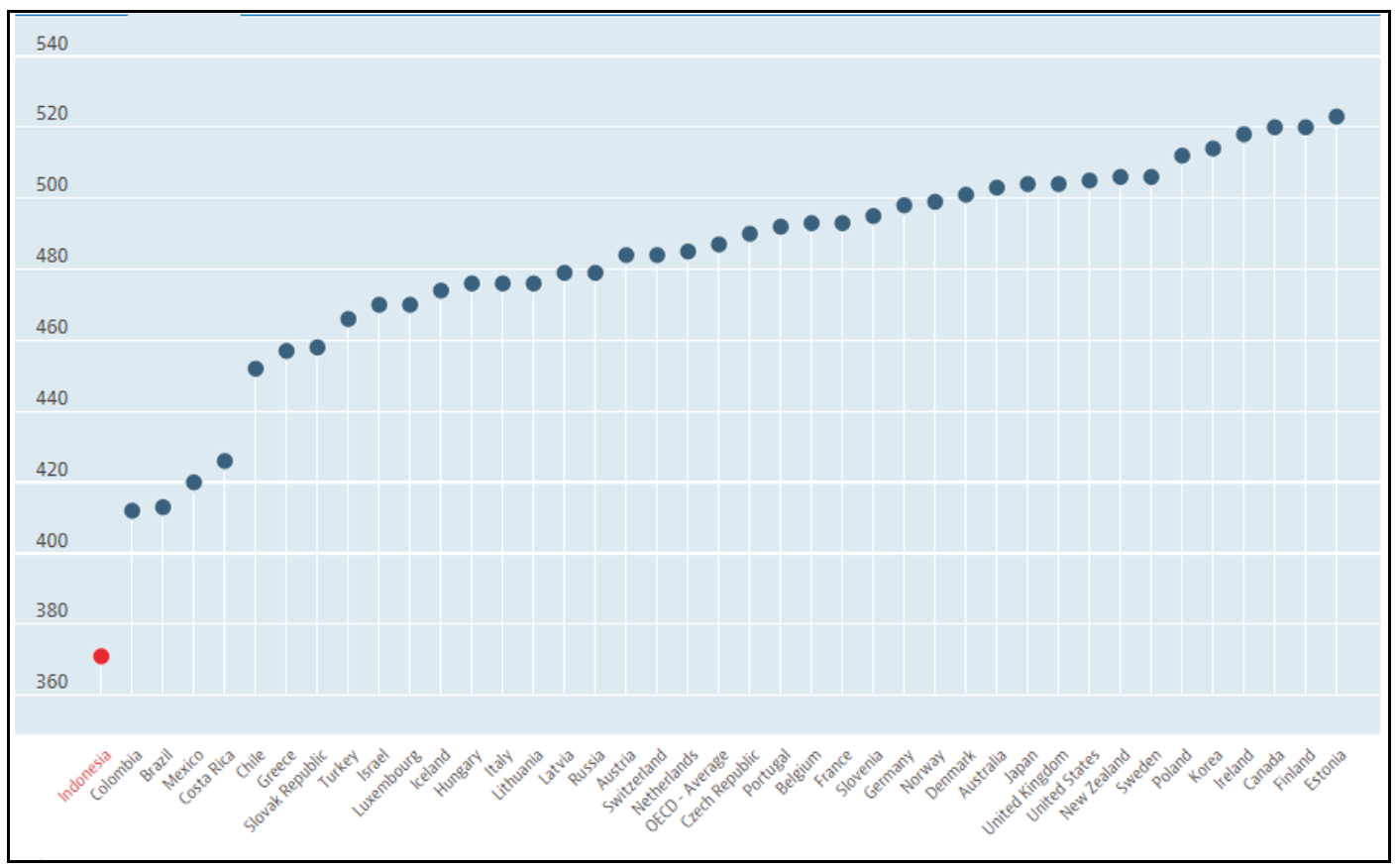

Fig. 1. Reading Performance (PISA) [21]. 


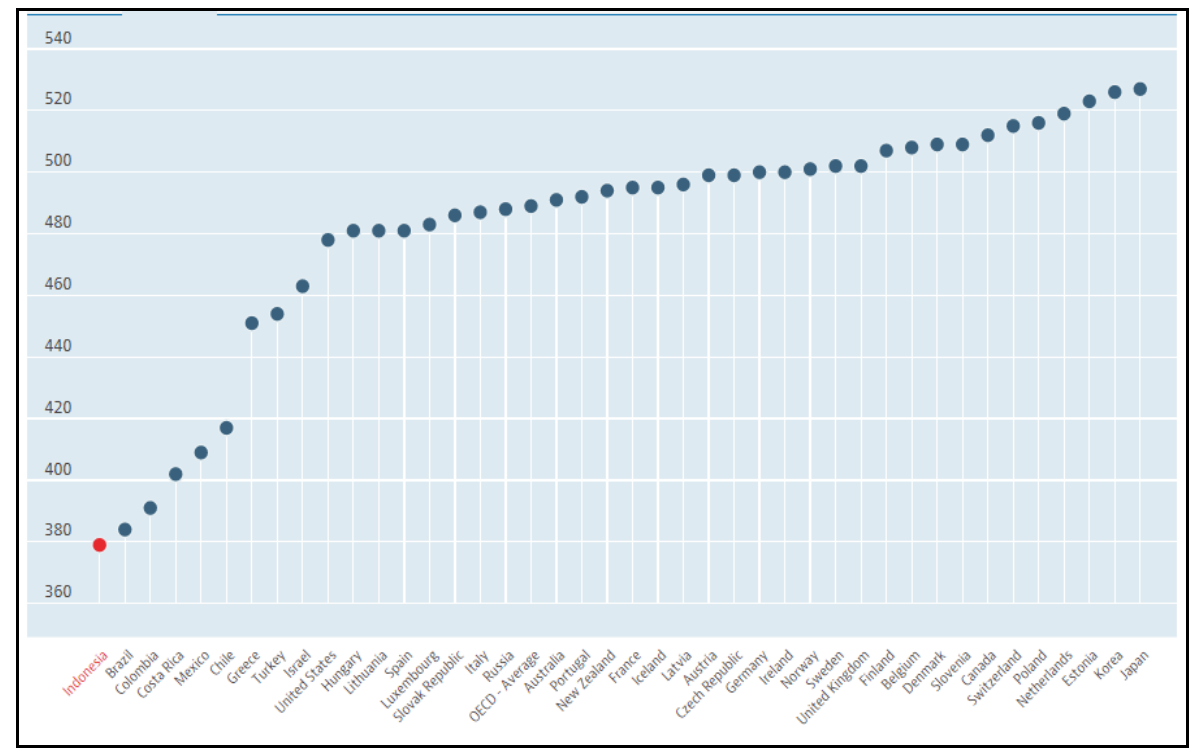

Fig. 2. Figure 2. Mathematics Performance (PISA) [21].

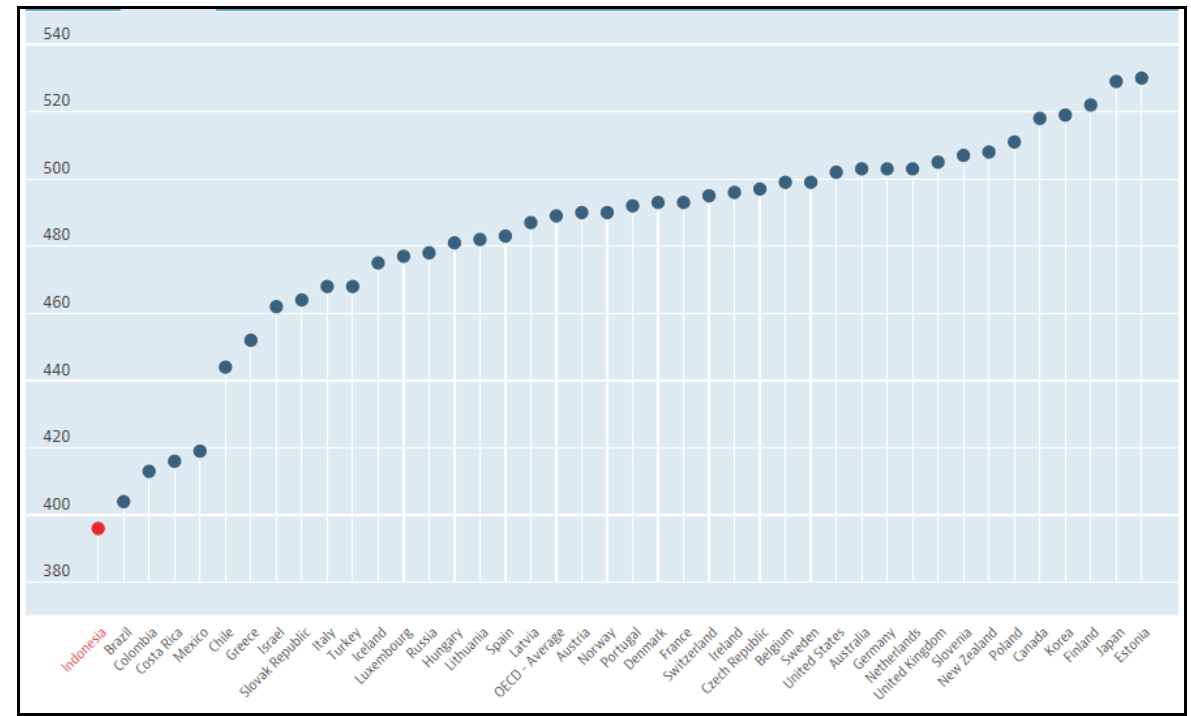

Fig. 3. Figure 3. Science Performance (PISA) [21].

The data that has been presented is the backround of the importance of and the need to improve the education quality in Indonesia. In this case, the government continues to carry out evaluations in the education sector to improve the quality of education in Indonesia, namely by increasing the existing deficiencies. Lacking in curriculum implementation, the government continues to review the curriculum that is suitable for application in Indonesia. Therefore, the 2013 curriculum is being implemented with the aim of improving the quality of education in Indonesia [19].

Basically, comprehensive components are needed to improve the quality of education in Indonesia and to keep up with the times in the $21^{\text {st }}$ century. The main components must be implemented comprehensively according to Andrew and Willingham [22] include (1) A more adaptive curriculum that is the development of curriculum content which is able to stimulate thinking and skills in relation to the challenges of time. (2) A more participatory learning model, namely the development of a learning model that is directed at developing collaborative, interactive, creative, and innovative skills; and (3) A more meaningful assessment, which is the development of a Contextual Assessment model and the demand for Higher Order Thinking Skills (HOTS). The aforesaid components must be carried out and integrated simultaneously.

Improving the quality of education in Indonesia is one of the goals of the sustainable development program. Based on 
the three main components above in improving the education quality in Indonesia, the urgency of implementing higher-order thinking-oriented learning and assessment or better known as higher-order thinking skills (HOTS) can be used as principal to improve the quality of human resources in Indonesia. Thus, based on the aforesaid issues, this study aims to investigate 1) The urgency of HOTS-oriented learning towards the quality of education in facing Indonesia SDGs 2030; 2) The urgency of HOTS-oriented assessment towards the quality of education in facing Indonesia SDGs 2030.

\section{THEORETICAL FRAMEWORK}

\section{A. Higher-Order Thinking Skills Learning}

Countries invest in education expecting that it will contribute to their long-term welfare and economic sustainability. The problem, at present, is that although the necessities in the world of work have changed, there is no change in education [2]. Today, the world in facing Industry 4.0 urgently needs a generation of knowledge who has ability to face new and more complex technological challenges [23][24]. To respond to this, in the field of education, especially in the learning process, it must be designed very well to be meaningful and in accordance with the objectives and also with student needs in order to prepare them for their future [25]. The $21^{\text {st }}$ Century learning places a greater emphasis on students' ability to perform Higher Order Thinking Skills (HOTS) [4][26][27].

Conceptually, HOTS is an extension of the use of the mind to meet new challenges. HOTS is seen as a thoughtful function of the mind's ability to solve challenging situations [28][29]. According to Nofrion and Wijayanto [30], HOTS learning is learning that develops students' higher-order thinking skills, which is more than just the ability to memorize/remember, restate, remember and refer without scientific reason (reading). Questions, assignments and problems in learning are useful for:

- Transmitting one notion to another,

- Processing and applying an information,

- Looking for relations from various sources,

- Using the information to solve the problem,

- Critically reviewing ideas and information.

This higher order thinking skills can be improved through learning process activities that lead to an increase in $4 \mathrm{C}$ skills (communication, collaboration, critical thinking, and creativity). Students must practise the skills and improve learning to be able to conquer global challenges, such as basic reasoning abilities (critical thinking), the ability to communicate effectively, being creative and taking care of issues through negotiation and collaboration [31]. This $4 \mathrm{C}$ skills must be possessed by $21^{\text {st }}$ century students in order to be ready to face a development of the times that is increasingly sophisticated. This 4C skills can be done by applying learning models such as Project Based Learning, Problem Based
Learning, Cooperative Learning [32]. The framework of the $21^{\text {st }}$ century skills is presented in Figure 4 below:

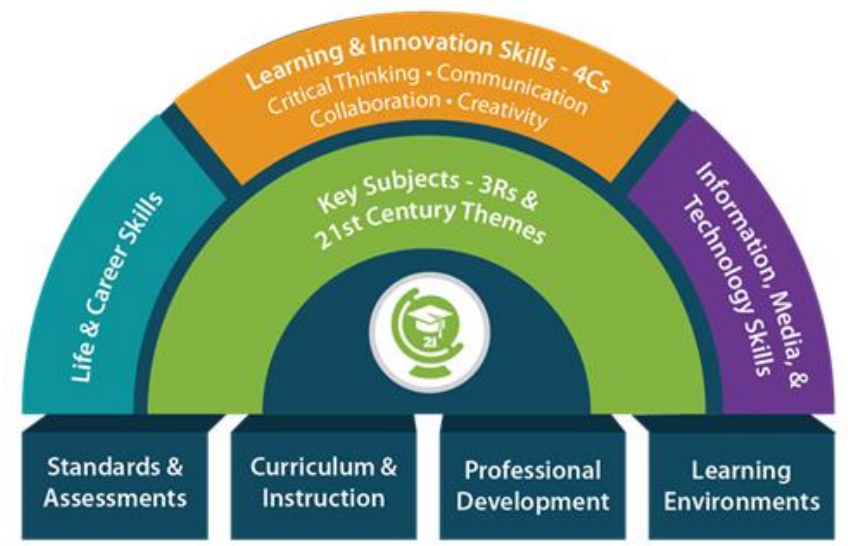

Fig. 4. The Framework of $21^{\text {st }}$ Century Learning [33]

A description of the $21^{\text {st }}$ century learning framework according to BSNP [34] and Wijaya, et al. [35] is as follows:

- Students are able to think critically, laterally, and systemically, particularly in the problem-solving context through Critical-Thinking and Problem-Solving Skills;

- Students are trained to be able to communicate and collaborate effectively with various parties through the ability to communicate and collaborate (Communication and Collaboration Skills);

- The ability to create and renew (Creativity and Innovation Skills) means that students are able to develop their creativity to produce various innovative breakthroughs.

- Information and Communications Technology Literacy aims to enable students to take advantage of information and communication technology to improve performance and daily activities;

- Contextual Learning Skills means being able to experience contextual independent learning activities as part of personal development;

- Information and media literacy skills means being able to comprehend and use various types of communication media to deliver numerous ideas and carry out collaborative activities and interactions with various parties.

Framework in $21^{\text {st }}$ century learning is a step that can refine the quality of students in the learning process, in a frame of mind designed to carry out a learning activity that improve students' $4 \mathrm{C}$ skills in class, on the other hand this activity is a step to improve students' thinking skills from low-level thinking to high-level thinking. High-level thinking skills become a demand for $21^{\text {st }}$ century learning in this era of revolution 4.0 


\section{B. Higher-Order Thinking Skills Assessment}

Assessment is described as the process of gathering information aimed at making decisions about students, curriculum programs, and educational rules [36][37]. Assessment is carried out in order to improve teaching or learning, and it is done during the teaching process [38]. At the time of the learning process carried out by teachers in Indonesia, the classroom greatly affects the student learning process. It is because learning outcomes are important parameter in determining the level of understanding and knowledge possessed after the learning process takes place [39]. Assessment activities are able to assist learning if they provide information that both teachers and students can use as feedback in assessing themselves and each other [40].

At the beginning of this decade, the assessment that is currently trending in Indonesia is an assessment that is able to refine students' thinking skills, namely higher-order thinking skills. Stein and Lane [41] and Ananda [42] define HOTS as the use of complex thinking and the use of different approaches, also the ability to complete tasks with multiple solutions [43][44] which require effort to find a structure or solutions [45][46][44]. Basically, the ability to analyze, evaluate, and create is often referred to as Higher-Order Thinking Skills [47][48][49][50].

Higher order thinking skills (HOTS) are the abilities to analyze (C4), evaluate (C5) and create (C6), and practically in the classroom, teachers must have knowledge and skills to support their profesionalism so that can also support higher order thinking skills of students [51]. The cognitive taxonomy according to Anderson and Krathwohl is presented in the following figure 5 [47]:

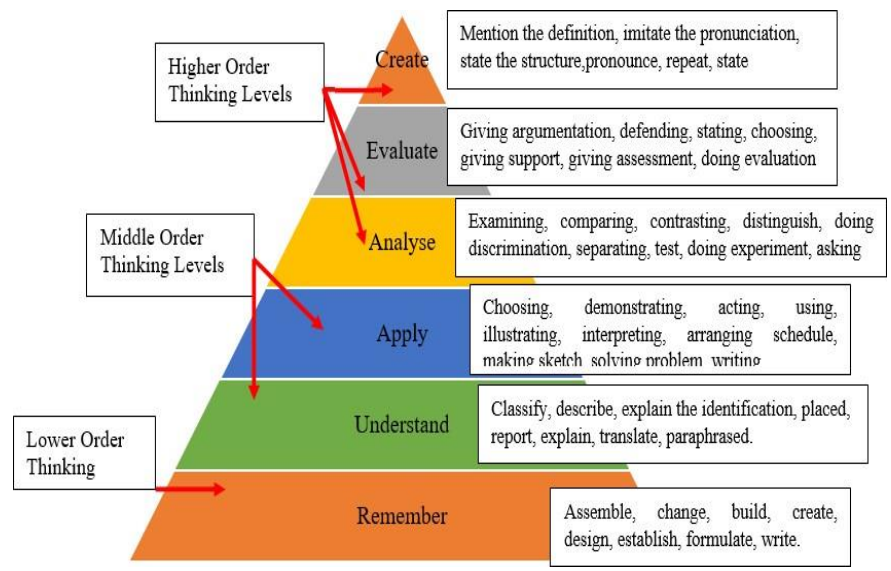

Fig. 5. Cognitive Taxonomy [47].

In the implementation of HOTS-oriented assessment in the classroom during the learning process in order to improve the quality of student thinking, the teacher should be able to apply the following operational verbs in writing item questions on measuring student learning outcomes. The details of cognitive taxonomy categories included with operational verbs that are higher-order thinking oriented skills according to Anderson and Krathwohl [52] are presented in Table 1 below:
TABLE I. The Details of the Cognitive TAXonomy [52]

\begin{tabular}{|c|c|c|}
\hline $\begin{array}{c}\text { Cognitive Process and } \\
\text { Category }\end{array}$ & Other terms & Definition \\
\hline \multicolumn{3}{|c|}{ C4 Analyze } \\
\hline 4.1 Distinguishing & $\begin{array}{l}\text { Isolate, Sort, Focus, } \\
\text { Choose }\end{array}$ & $\begin{array}{l}\text { Distinguishing parts of the } \\
\text { subject matter that are } \\
\text { relevant and irrelevant. }\end{array}$ \\
\hline 4.2 Organizing & $\begin{array}{l}\text { Finding Coherence, } \\
\text { Integrating, } \\
\text { Outlining, Describing } \\
\text { roles, Structuring }\end{array}$ & $\begin{array}{l}\text { Determining how the } \\
\text { elements work or function } \\
\text { in a structure. }\end{array}$ \\
\hline 4.3 Attributing & Deconstruct & $\begin{array}{l}\text { Determining the point of } \\
\text { view, bias, value or intent } \\
\text { behind the subject matter. }\end{array}$ \\
\hline \multicolumn{3}{|l|}{ C5. Evaluate } \\
\hline 5.1 Checking & $\begin{array}{l}\text { Coordinating, } \\
\text { Detecting, } \\
\text { Monitoring, } \\
\text { Assessing }\end{array}$ & $\begin{array}{l}\text { Find errors in a process or } \\
\text { product; find the effective } \\
\text { procedure that is being } \\
\text { practiced. }\end{array}$ \\
\hline 5.2 Criticizing & Assessing & $\begin{array}{l}\text { Find } \\
\text { between a product and } \\
\text { external criteria; determine } \\
\text { whether a product has } \\
\text { external consistency, find } \\
\text { the accuracy of a procedure } \\
\text { to solve problems. }\end{array}$ \\
\hline \multicolumn{3}{|c|}{ C6. Create } \\
\hline 6.1 Formulating & Making a hypothesis & $\begin{array}{l}\text { Making hypotheses based } \\
\text { on criteria. }\end{array}$ \\
\hline 6.2 Planning & Designing & $\begin{array}{l}\text { Planning a procedure for } \\
\text { completing a task. }\end{array}$ \\
\hline 6.3 Producing & Constructing & Creating a product. \\
\hline
\end{tabular}

Based on the table above, basically these three aspects can be improved through the following learning activities:

- C4 cognitive aspect (Analysis), is an aspect of analysis that involves a process of breaking the material into small parts and determining the relationship between parts and the overall structure [52]. This aspect can be improved through the implementation of problem-based learning, problem solving learning in class.

- C5 cognitive aspects, is an aspect of evaluation that is defined in making decisions based on criteria and standards. These criteria are determined by students [52]. This aspect can be improved through the implementation of problem-based learning and problem solving in class.

- C6 cognitive aspect, is an aspect that creates and involves the process of following the elements into a coherent whole [52]. This aspect can be improved through the implementation of project-based learning in class.

\section{Sustainable Development Goals (SDGs)}

Sustainable development aims to preserve and improve the quality of life constantly and in the long term. Sustainable development is a process that aims to improve the quality of 
life in a broad sense, which should not be limited to financial wealth or material welfare but consists of environmental quality, implementation of democratic rights, access to natural resources, services and also institutions provided by the community, together with full physical and mental health, leisure, safety, and security [53]. Practically, sustainable development itself is a global action plan agreed upon by world leaders including Indonesia, population destruction, reduction and environmental protection. The SDGs contain 17 Goals and 169 Targets which are expected to be achieved by 2030 . The 17 programs are as follows table 2 :

TABle II. Sustainable Development Goals (SDGs) Program [54]

\begin{tabular}{|l|l|}
\hline Goal & \multicolumn{1}{|c|}{ Sustainable Development Program } \\
\hline 1 & End poverty in all its forms everywhere \\
\hline 2 & End hunger, achieve better living food security and nutrition and support sustainable agriculture \\
\hline 3 & Ensure healthy lives and supporting wellbeing for all ages \\
\hline 4 & Ensure education is inclusive and of equal quality, while also supporting lifelong learning opportunities for all \\
\hline 5 & Achieve gender equality and empower all women and girls \\
\hline 6 & Ensure availability and sustainable management of clean water and sanitation for all \\
\hline 7 & Ensure access to affordable, reliable, sustainable and modern energy for all \\
\hline 8 & Support inclusive and sustainable economic growth, a full and productive workforce and decent work for all \\
\hline 9 & Build resilient infrastructure, support inclusive and sustainable industrialization and foster innovation \\
\hline 10 & Reduce inequality within and between countries \\
\hline 11 & Build cities and settlements that are inclusive, safe, resilient and sustainable \\
\hline 12 & Ensure sustainable consumption and production patterns \\
\hline 13 & Take urgent action to combat climate change and its impacts \\
\hline 14 & Conserve and sustainably use marine, oceanic and maritime resources for sustainable development \\
\hline 15 & $\begin{array}{l}\text { Protect, restore and support the sustainable use of terrestrial ecosystems, manage forests sustainably, combat desertification, and inhibit and } \\
\text { reverse soil degradation and inhibit the loss of biodiversity }\end{array}$ \\
\hline 16 & $\begin{array}{l}\text { Support a peaceful and inclusive society for sustainable development, provide access to justice for all people and build effective, accountable } \\
\text { and inclusive institutions at all levels }\end{array}$ \\
\hline 17 & Strengthen the implementation measurement and revitalize global partnerships for sustainable development \\
\hline
\end{tabular}

Based on the $17 \mathrm{SD}$ points above, there is number four relating to the quality of education. Education for sustainable development can support every human being in acquiring the knowledge, skills, attitudes and values that are needed to build a sustainable future [55][56]. From a development perspective, quality education has a significant impact on national development [57]. The quality of education is actually the result of the process and other factors that can affect student learning outcomes. Quality education can provide great opportunities to produce capable human resources.

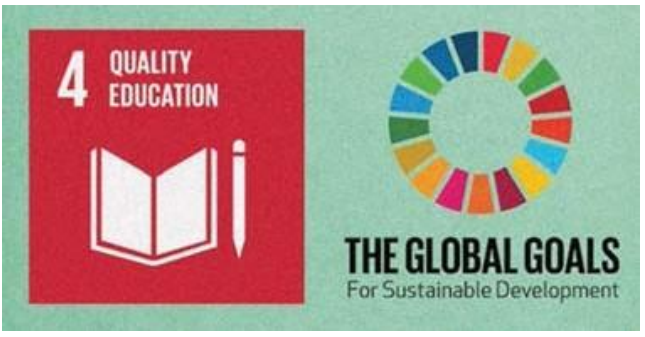

Fig. 6. Education Sustainable Development [58].

ESD (Education Sustainability Development) in figure 6, is a lesson needed to improve the human life quality today and, in the future, where competencies related to ESD in the form of knowledge, skills and attitudes or ESD values are carefully integrated in learning [59]. There are four main priority supporting the implementing ESD, which are (1) fostering and improving the education quality; (2) reorienting the existence of education at all levels to address sustainable development; (3) increasing public awareness of the concept of continuing education; (4) labor train [59][60].

According to UNESCO [55], the goals relate to inclusive and equitable quality of education and lifelong learning opportunities for all people. The targets are: 1) free, fair and qualified primary and secondary education 2) access to qualified education since an early age, early childhood development, and pre-primary education, 3) equivalent access for women and men to technical education 4) the increased number of youth and adults who have relevant technical and vocational skills for employment and entrepreneurship 5) gender gaps elimination at all levels of education and vocational training 6) a literate generation (all youth and adults are literate) 7) the acquisition of knowledge and skills needed by the students in order to promote sustainable development through ESD in all aspects 8) building and refining educational facilities for students with disabilities and becoming sensitive to gender issues as well as providing safe, non-violent, inclusive and effective learning environment for all learners 9) expanding globally the number of scholarships for enrollment in higher education, vocational training, and ICT, technical, technical and scientific programs 10) increasing the supply of qualified teachers, including through international cooperation for teacher training in development and at least developed countries. 


\section{METHODS}

The research method used is descriptive qualitative with literature review. According to Sukmadinata [61], literature review is a series of studies which is related to the literature study as data collection methods or, in other words, it is a research conducted in libraries which its research objects are investigated through a variety of literature such as books, scientific journals, encyclopedias, newspapers, magazines, and documents. Data collection can be done by finding some relevant data or information, namely reputable journals, both international and national indexed journals, as well as several books and website pages that support updates in this article related to the urgency of learning and HOTS-oriented assessment towards education quality in facing Indonesia's 2030 sustainable development goals.

\section{RESULTS AND DiSCUSSION}

\section{A. The urgency of HOTS-oriented learning towards Quality Education in facing of Indonesia SDGs 2030}

Education for sustainable development also refers to the learning needed to maintain and improve the quality of life for future generations [62][63]. Quality of education is basically essential for a country as it can affect the quality of its human resources. Education quality can be seen from the national education standards applied to the country [19]. In principle, all levels of education require students to have high HOTS scores $[4][64][65][66]$. HOTS is a skill that is required by every person in any educational environment [67].

ATCS (assessment and teaching for $21^{\text {st }}$ century skills) concludes four main concepts related to $21^{\text {st }}$ century skills, namely how to think, how to work, work tools and life skills. Ways of thinking can include creativity, critical thinking, problem solving, decision making and learning, in this case all these ways of thinking are included in HOTS-oriented learning. Conceptually, there is a difference between learning low-order thinking skills and higher-order thinking skills, and it can be seen in the following table 3 .

TABLE III. THE DIFFERENCES OF LOTS AND HOTS LEARNING [68]

\begin{tabular}{|l|l|}
\hline \multicolumn{1}{|c|}{$\begin{array}{c}\text { Student activities in LOTS } \\
\text { learning }\end{array}$} & \multicolumn{1}{c|}{$\begin{array}{c}\text { Student activities in HOTS } \\
\text { learning }\end{array}$} \\
\hline Passive in thinking & Active in thinking \\
\hline Problem Solving & Formulate problems \\
\hline Reviewing simple problems & Reviewing complex problems \\
\hline Convergent thinking & $\begin{array}{l}\text { Think divergent and develop } \\
\text { ideas }\end{array}$ \\
\hline $\begin{array}{l}\text { Learning from the teacher as the } \\
\text { main source of information }\end{array}$ & $\begin{array}{l}\text { Finding information from } \\
\text { various sources }\end{array}$ \\
\hline $\begin{array}{l}\text { Practice solving questions and } \\
\text { memorizing }\end{array}$ & $\begin{array}{l}\text { Critical thinking and solving } \\
\text { problems creatively }\end{array}$ \\
\hline Prioritizing factual knowledge & $\begin{array}{l}\text { Analytical thinking, evaluative } \\
\text { thinking, and making decisions }\end{array}$ \\
\hline
\end{tabular}

Thinking skills are the most basic abilities of every individual. The main task of educators is to provide space and facilities for students to become effective and efficient thinkers through the process of correct thinking. Things that educators can do include providing appropriate teaching strategies, methods, and materials to facilitate the growth of higher order thinking skills [69][70]. To improve student thinking, the teacher's strategy in the learning process in the classroom must be implemented to improve the thinking of the 4Cs super skills which consists of critical thinking, creative thinking, collaboration thinking and communication thinking. Here is an illustration from the $4 \mathrm{Cs}$ Super Skills on $21^{\text {st }}$ century learning in figure 7.

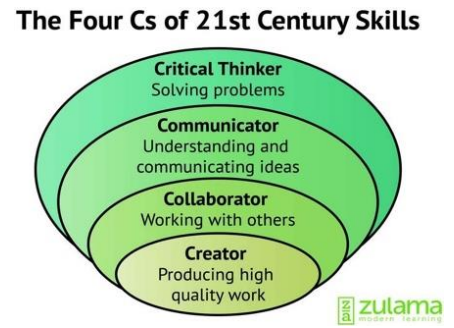

Fig. 7. The 4Cs super skills [71][72]

The four Cs of $21^{\text {st }}$ Centery Skills are four skills that must be mastered by $21^{\text {st }}$ century students, basically these four skills can improve students' higher order thinking skills. These four abilities can be conceptually defined as follows:

1) Critical thinker skills: Critical thinking skills create problem solving including reasoning effectively, using systems of thinking, making sound judgments and decisions, and solving problems [73]. The term 'critical thinking' or expression refers to critical thinking and behavioral skills such as analyzing and interpreting meaningful data [74]. According to Liu, Frankel and Crotts [75], they create an operational definition of critical thinking that integrates previous theoretical frameworks and empirical research. They identify five main dimensions namely (1) evaluating the evidence; (2) analyzing and evaluating arguments; (3) understand the implications and consequences; (4) generate original arguments; (5) understand the causes [76]. Critical thinking is considered a high-level thinking or higher order thinking skill. These skills are also needed to analyze and manipulate information [77].

In line with the opinion of Keshta and Seif [78], critical thinking skills are associated with high-level cognitive skills, such as analyzing, synthesis, and evaluation [79]. Then, critical thinking also helps testing the validity and reliability of our beliefs contributing to sound and accurate judgments. In education, students are expected to have self-discipline skills in thinking, drawing logical, objective and fair conclusions. For this purpose, teachers should also have critical thinking skills [80][77]. There is a huge connection between basic reasoning abilities and applied comprehension. Students who are gifted in basic reasoning have higher cognitive learning outcomes than those who are not, and critical thinking has a significant effect on academic achievement [79][81]. 
Communication is defined as a person's ability to articulate thoughts and ideas effectively by using oral, written, and nonverbal communication skills in various forms and contexts [82][83]. An important aspect of communication is that it demands a two-way exchange of information (messages and feedback) that forms a connection between two or more people. Both business and education researchers also agree that communication skills are very significant for $21^{\text {st }}$ century citizens [73].

2) Collaborator skills: Collaborative skills, including working effectively and respectfully with multiple teams, exercising flexibility and willingness to achieve common goals, and taking shared responsibility for collaborative work while assessing individual contributions of team members [73]. P21 [84] in Germaine [73], defines collaboration as the ability to "work effectively in a diverse team of compromises in order to achieve common goals, and appreciate the contribution of each individual". Following are the many benefits of collaboration according to Trilling and Fadel [85] including (1) providing access to skills and strengths, (2) developing skills, (3) solving problems and innovating faster, (4) making work more efficient, and (5) increase job satisfaction.

3) Creator skills: Creativity and innovation skills, which include thinking about creating new things and valuable ideas; and outlining, refining, analyzing, evaluating ideas, enhancing and maximizing efforts [73].

Creative individuals can utilize an assortment of thought creation methods, including conceptualizing, mindmapping, doodling, and charts. They are keen on evaluating unique thoughts, explaining, refining, and attempting to improve them. Creativity regularly includes working on projects with others and being open to various points of view. Innovative individuals work to be creative and unique, and they view disappointment as a chance to learn from mistakes [82]. To understand more deeply about The "Four Cs" there is a concept from Bubbls.us which is presented in Figure 8.

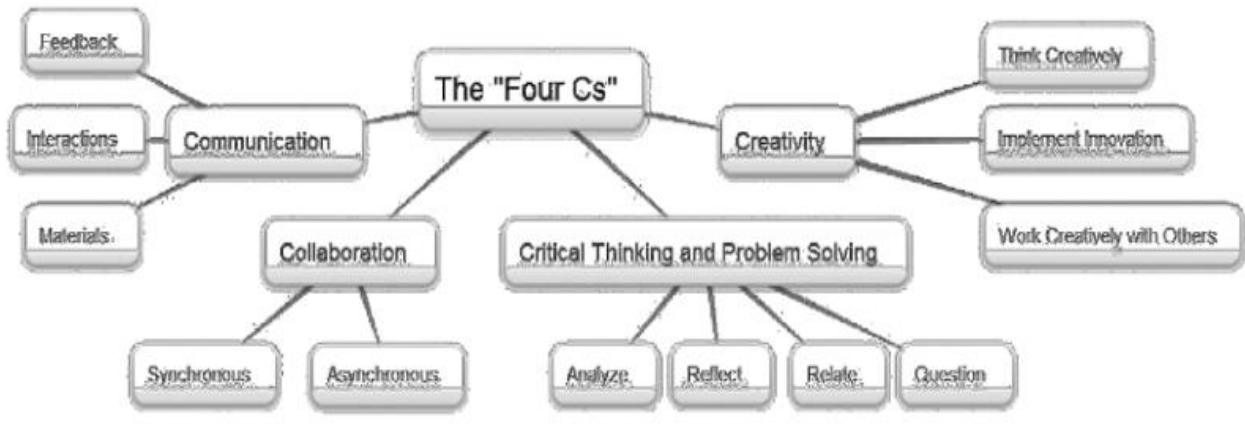

Fig. 8. The "Four Cs" of 21st Century Skills created with Bubbl.us [83]

The problems that will be faced by students in industrial development schools 4.0 are very diverse, so HOTS (High Level Thinking Skills) is needed. Therefore, there are many abilities that students should be able to develop, including 4C. In order to have the results (students) which match the industrial needs of the 4.0 era, learning must be updated and innovated [86]. According to Saavedra and Opfer [31], it is suggested that these nine principles are used to teach $21^{\text {st }}$ century skills: (1) make learning relevant to 'big picture'; (2) teach with discipline; (3) develop the ability to think lower and higher to encourage understanding in different contexts; (4) foster the transfer of learning; (5) teach about how to "learn to learn" or metacognition; (6) correct misunderstandings directly; (7) promote teamwork, (8) utilize technology to support learning; and (9) increase student creativity.

In this case, students must be the main actors in making meaning of their experiences. Some studies highlight that student involvement in the learning process is more vital to learning [87][88][89]. In other words, student involvement in the process should be the focus of assessing teaching effectiveness [16]. Because basically what teachers do in the learning process has a significant impact on student learning [16][90][91]. Minister of Education and Culture Regulation
Number 22 of 2016 concerning process standards using 3 (three) learning models which is expected to shape scientific, social behavior and develop a sense of curiosity. The three models are: (1) a learning model through discovery / inquiry learning, (2) a problem-based learning (PBL) model, (3) a project-based learning model. PPA).

- The learning model, through discovery / inquiry learning, is an understanding of concepts, meanings, and relationships through an intuitive process to finally arrive at a conclusion. Discovery occurs when the individual is primarily involved in the use of his mental processes to discover some concepts and principles. Discovery is done through observation, grouping, measurement, prediction, determination, and inference. The afiresaid procedure is called cognitive process, while discovery itself is the mental process of assimilating concepts and principles in the mind [92]. This learning is very important for educated people and basic education strategies for scientifically literate individuals [93][94]. The goal of the Discovery Learning learning model will help students improve their critical thinking skills [95]. According to Bruner, the syntax of the Discovery Learning model includes 
[96] (1) giving stimulation, (2) statement / problem identification, (3) data collection, (4) data processing, (5) proofing and (6) drawing conclusions/generalizations.

- Problem-based learning (PBL) is a learning model that uses the various thinking abilities of students individually and in groups as well as a real environment to solve problems so that they are meaningful, relevant, and contextual [97][92]. Problem-based learning (PBL) is a learning and teaching strategy that is planned to involve students in solving real-world problems [98]. According to Fajrilia [99] Problem based learning is a learning model that focuses on students, and it is contextual. Students are directly involved in finding solutions to a problem so that the model is able to improve higher-order thinking skills. Meanwhile, the syntax of the Problem-based Learning model according to Arends [100] includes (1) the orientation of students on problems; (2) Organizing students to learn; (3) Guiding individual and group investigations; (4) Developing and presenting works; and (5) Analyze and assess the problem-solving process.

- The project-based learning model is a form of studentcentered learning. Which aims to develop more independence in students [101]. The benefits of PjBL allow students to demonstrate higher abilities [102][103]. In this case, PjBL facilitates students to collaborate on conceptual understanding, apply previous knowledge, and to acquire skills. It can integrate several disciplines to create a project [104]. The application of the Project-based Learning model according to Ariyana [92] includes (1) Topics / material that students learn are contextual topics and are easily designed to be interesting projects / works; (2) Students are not led to produce only one project (one student produces one project); (3) The project does not have to be completed in 1 meeting but completed in 3-4 meetings; (4) The project is a form of problem solving so that the creation of a project leads to an increase in learning outcomes; (5) Ensure that materials, tools and media needed to make the project are available in the surrounding environment and directed to utilize used materials / waste to make them valuable and useful; and (6) Authentic assessment emphasizes the ability to design, implement, find, and convey products to others.

The learning model can also be disclosure/discovery, but problem-based learning models, project-based learning models are the three models that are effective for improving high-level thinking (HOTS) of students during the teaching and learning process. It means that the teacher's urgency is in the implementation of HOTS learning at every learning in class because basically the main actor of education for sustainable development is the teacher or educator who is seen as an effective agent of change [105][106][107][63].

\section{B. The Urgency of HOTS-oriented Assessment towards the} Quality of Education in Facing Indonesia's 2030 SDGs

The OECD supports these discussions and shares member states' commitments to a new education and universal agenda with a focus on learning outcomes and skills for all [58]. Good learning outcomes are when individuals exceed expectations to memorize and repeat interrupted facts and knowledge (with certain applications), can indirectly seize opportunities to understand difficult concepts and complex ideas, evaluate new ideas, and create the essence of their own insights. In this case the role of the teacher is very important, the teacher can use the student's response as an opportunity to evaluate their readiness to learn more deeply, and introduce new concepts that are appropriate to challenge their thinking [108]. In the 2013 curriculum, the Ministry of Education and Culture also made improvements to content standards and assessment standards, both of which focus on Higher-Level Thinking Skills (HOTS) [19][109]. Related to higher-order thinking assessments, Mohamed and Lebar [110] designed an integrated structure regarding the item elements in an assessment to measure HOTS which can be seen in Figure 9.

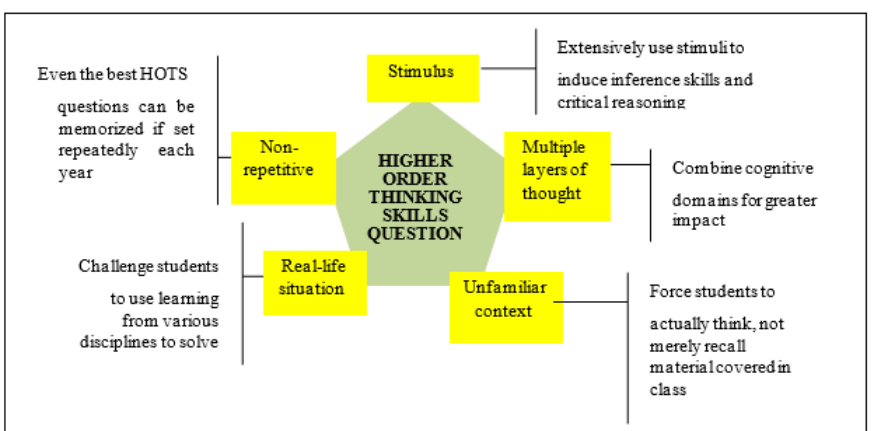

Fig. 9. Figure 6. The Item Elements of Assessment to Assess HOTS [110].

In measuring the HOTS assessment, it is necessary to form and train students' thinking to analyze, evaluate and create or create in line with the three HOTS-oriented learning model designs that have been described in the previous sub-section. According to Brookhart [111], indicators to be able to measure analytical skills are to focus on main ideas, analyze arguments, and compare and contrast. Indicators that can measure evaluation ability are the ability to make decisions or methods to be in line with the desired goals. Indicators to measure the capacity of creation are taking care of issues with more than one solution, planning an approach to tackle issues, and making something new. Indicators of logical and reasoning abilities are substance, reasoning and evidence, and clarity of language style.

The assessment instrument or HOTS questions are questions that require high-level thinking skills. In shaping better student quality, questions like this must indeed be developed by the teacher properly and applied in the class they are teaching. HOTS or higher order thinking skills are divided into four groups, namely problem solving, decision making, critical thinking, and creative thinking [36]. According to Krathwohl [44][112] in a revision of Bloom's Taxonomy: an 
overview - Theory into Practice states that the indicators for measuring HOT are as follows:

- Indicators that can measure $\mathrm{C} 4$ cognitive level questions (analyze) include: 1) analyzing incoming information and dividing or structuring information into smaller parts to recognize patterns or relationships, 2) being able to recognize and differentiate causal and effect factors from a complicated scenario, 3) identifying/formulating questions. The following is the implementation of the measurement instrument with the C4 cognitive level (analyzing).

Look at the following picture.
uppermost
mantle
Fig. 10. Subduction.
https://en.wikipedia.org/wiki/Subduction trench
When the oceanic crust collides with the continental crust, it tends to
sink into the bowels of the earth, this is because ...
A. Higher density of oceanic crust
B. Oceanic crust is thinner than continental crust
C. The continental crust is made up of silica and aluminum
D. The continental crust is composed of the mineral magnesium
E. The oceanic crust is beneath the continental crust
Oceanic

- Indicators to measure C5 cognitive level questions (evaluate) include: 1) providing an assessment of a solution, ideas, and methodology using suitable criteria or existing standards to ensure the value of its effectiveness or benefit, 2) making hypotheses, 3) criticizing and perform the test, 4) accepting or rejecting a statement based on predetermined criteria. Here is the implementation of the measurement instrument with a cognitive level of C5 (evaluating).

\begin{tabular}{|c|}
\hline C5 Question (Evaluate) \\
\hline Read the following statement: \\
1) Each time zone has a distance difference of $15^{0} \mathrm{BT}$ \\
2) The WITA area follows the GMT +8 standard time \\
3) Papua region is the earliest area to start morning activities in Indonesia \\
4) The western part of Indonesia is 3 hours apart from the eastern part of \\
Indonesia \\
The correct statement with respect to time zones in Indonesia is ... \\
A. (1), (2), and (3) \\
B. (1) and (3) \\
C. (2) and (4) \\
D. (3) and (4) \\
E. (1), (2), (3), and (4)
\end{tabular}

- Indicators for measuring C6 cognitive level problems (creating) include: 1) generalizing an idea or way of looking at something, 2) designing a way to solve a problem, 3) organizing elements or parts into new structures that have never been existed before. The following question is the implementation of the measurement instrument with a cognitive level of C6 (creating).

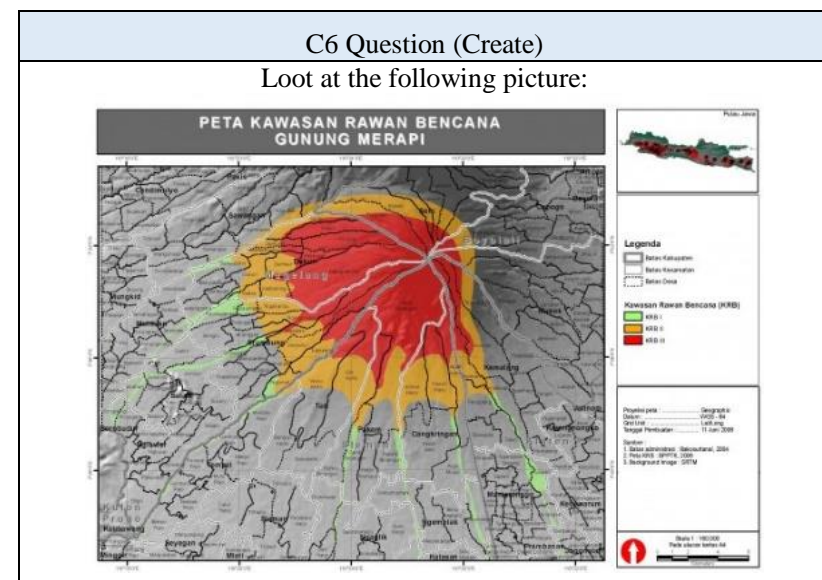

Fig. 11. Figure 8. Map of Mount Merapi Disaster Prone Areas Sumber: http://bnpb.go.id

Based on the map above, it is an overlay of several maps to produce a new map. The thematic map that is overlaid to make the map on top includes ...

A. Population distribution map, lava flow map, topographic map B. Topographic maps, land use maps, lava flow maps

C. Population distribution map, lava flow map, land use map

D. Risk map of disaster area, map of lava flow, map of population distribution

E. Topographic maps, population distribution maps, land use maps

The implementation of assessment using HOTS-oriented measurement instruments at cognitive levels $\mathrm{C} 4, \mathrm{C} 5$, and C6 can improve students' higher thinking skills. This means that in this case the integration of ESD is by Teachers/Educators since the educators are agents of change who provide the educational response needed to achieve the SDGs. The knowledge and competencies they possess are very important to restructure the educational process and educational institutions towards sustainability. Teachers are required to continue to face this challenge by reorienting themselves towards ESD. However, efforts to prepare teachers to implement ESD are still not advanced enough. There is still a lot of work that needs to be done to direct teachers towards education for sustainable development, both in terms of content, teaching methods and learning [113]. In this case, we should have the quality of education in Finland which is a country that has good quality education, but all of this is based on high quality teacher training [114]. The aim of such teacher training is to provide graduating teachers with the versatility and required knowledge and skills [115][116].

Education plays a significant role in preparing the human resources. Indonesia has also a highly qualified human 
resource. This is proven by the fact that the correlation of the education coefficient on the human resource development index is 0.99 . It means that education is great for contributing to increasing the welfare index [117]. Today, the world is confronting a challenge to characterize the educational indicators including access, value and quality for all levels of education that can be measured and tracked over time and on a global scale [58]. Full commitment from all levels of society is very important because education for sustainable development is a disciplined learning strategy that emphasizes values, thoughts, methodologies and structured policy decision making in accordance with changing world [118]. Basically, education is the best medium to build a nation to make a great nation in all sectors [117]. Opening the gates of education for all human beings is the only way to develop Indonesia's human resources.

\section{CONCLUSION}

In the current development, especially at the beginning of the $21^{\text {st }}$ century, the era of revolution 4.0, having several challenges in improving the quality of education of a country is indeed very urgent. Given the changing times, it requires several standard processes, especially in the field of education to improve the human resources quality. The use of strategies, methods, models and assessment instruments is used to improve a student's thinking ability. Today, particularly highthinking skills are becoming a hot issue in its implementation, this is done to improve the quality of Indonesian education, based on the research results of the Program for International Student Assessment (PISA). Indonesia is one of the countries that has a PISA score that can be categorized low compared to other countries. Thus, based on these problems the importance of implementing higher order thinking skills oriented learning in Indonesia, which in its application teachers or educators can use several design models such as discovery-inquiry learning, problem based learning and project based learning and cooperative learning, the application of some of these learning models is expected to be able to improve the ability to think critically, creatively, collaboration and student communication in the classroom so as to improve students' higher order thinking skills in class.

On the other hand, the implementation of the assessment also needs to be considered since basically a means of measuring the success of a teaching and learning process activity is to conduct assessments in class. In this case, HOTSoriented assessment is also urgent. It is done to improve students' ability to think, analyze, evaluate and create. So with the two urgent things above, educators should be truly competent in implementing higher order thinking skills (HOTS) oriented learning and assessment in the $21^{\text {st }}$ century, which is the main key to realizing high quality education in realizing sustainable development in Indonesia in 2030.

\section{REFERENCES}

[1] V. M. Robinson, M. Hohepa, and C. Lloyd, School leadership and student outcomes: Identifying what works and why, vol. 41. Australian Council for Educational Leaders Winmalee, 2007.

[2] A. Chalkiadaki, "A systematic literature review of 21 st century skills and competencies in primary education.," Int. J. Instr., vol. 11, no. 3, pp. $1-16,2018$

[3] "Rencana Perspektif Garis Besar Ketiga.” 2001.

[4] Y.M. Heong, J.M. Yunos, W. Othman, R. Hassan, T.T. Kiong, and M.M. Mohamad, "The needs analysis of learning higher order thinking skills for generating ideas," Procedia-Social Behav. Sci., vol. 59, pp. 197-203, 2012.

[5] D. Sugandi and L. Somantri, "Improving Geography Pre-Service Teachers'understanding Of Satellite Imagery Analysis Using Er Mapper Software With A Module,” Int. J. Educ., vol. 11, no. 1, pp. 59-67, 2018.

[6] C.S. Bernardino, Exploring education for sustainable development: Theory and Practice of ILS in Philippine Higher Education Institutions University of Alberta, 2000.

[7] D. Scott, Education, epistemology and critical realism. Routledge, 2013.

[8] H. Mahat and S. Idrus, "Education for sustainable development in Malaysia: A study of teacher and student awareness," Geogr. J. Soc. Sp., vol. 12 , no. 6,2017

[9] J. Zajda, Global pedagogies: Schooling for the future, vol. 12. Springer Science \& Business Media, 2010.

[10] A.C. Saputri, “Improving Students' Critical Thinking Skills in CellMetabolism Learning Using Stimulating Higher Order Thinking Skills Model.,’ Int. J. Instr., vol. 12, no. 1, pp. 327-342, 2019.

[11] I. Talmi, O. Hazzan, and R. Katz, "Intrinsic Motivation and 21stCentury Skills in an Undergraduate Engineering Project: The Formula Student Project.," High. Educ. Stud., vol. 8, no. 4, pp. 46-58, 2018.

[12] L.W. Anderson and R. Krathwohl, "Kerangka Landasan Untuk Pembelajaran, Pengajaran, dan asesmen (Revisi Taksonomi Pendidikan Bloom), terj," Agung Prihantoro. Yogyakarta: Pustaka Pelajar, 2015.

[13] A. Zohar, Higher order thinking in science classrooms: Students' learning and teachers' professional development, vol. 22. Springer Science \& Business Media, 2004.

[14] C.S. Sunal and M.E. Haas, Social Studies for the Elementary and Middle Grades: A Constructivist Approach. ERIC, 2002

[15] A.M. Noor, "Pedagogical Issues in Integrating Thinking Skills in the Classroom," EDUCARE, vol. 2, no. 1, 2009

[16] Z. Zerihun, J. Beishuizen, and W. Van Os, "Student learning experience as indicator of teaching quality," Educ. Assessment, Eval. Account., vol. 24, no. 2, pp. 99-111, 2012

[17] F.J. King, L. Goodson, and F. Rohani, "Higher order thinking skills Definitions, strategies, assessment," Cent. Adv. Learn. Assessment. Tallahassee, FL Florida State Univ., 1998

[18] S. Wang and H. Wang, "Teaching and learning higher-order thinking," Int. J. Arts Sci., vol. 7, no. 2, p. 179, 2014

[19] R.Y. Kurniawan and D. Lestari, "The development assessment instruments of higher order thinking skills on economic subject," Din Pendidik., vol. 14, no. 1, pp. 102-115, 2019.

[20] R. Craig, "Developing cognition and language proficiency through the acquisition and articulation of knowledge: Real world communication activities for engineering students in and across the disciplines," Int. J. Arts Sci., vol. 4, no. 10, p. 69, 2011.

[21] "Programme for International Student Assessment (PISA)," 2011. www.oecd.org.

[22] A.J. Rotherham and D. Willingham, "21st century," Educ. Leadersh., vol. 67, no. 1, pp. 16-21, 2009.

[23] J. Lee, I. Cameron, and M. Hassall, "Improving process safety: What roles for Digitalization and Industry 4.0?,” Process Saf. Environ. Prot., vol. 132 , pp. $325-339,2019$. 
[24] S.A.M. Najib, H. Mahat, and N.H. Baharudin, "The Level of STEM Knowledge, Skills, and Values among the Students of Bachelor's Degree of Education in Geography.," Int. J. Eval. Res. Educ., vol. 9, no. 1, pp. 69-76, 2020.

[25] H. Yusmanto, B.E. Soetjipto, and E.T. Djatmika, "The Application of Carousel Feedback and Round Table Cooperative Learning Models to Improve Student's Higher Order Thinking Skills (HOTS) and Social Studies Learning Outcomes.," Int. Educ. Stud., vol. 10, no. 10, pp. 3949, 2017.

[26] G.M. Saido, S. Siraj, A.B. Bin Nordin, and O.S. Al_Amedy, "Higher order thinking skills among secondary school students in science learning,” MOJES Malaysian Online J. Educ. Sci., vol. 3, no. 3, pp. 1320, 2018.

[27] D. Shukla and A. P. Dungsungnoen, "Student's Perceived Level and Teachers' Teaching Strategies of Higher Order Thinking Skills: A Study on Higher Educational Institutions in Thailand.,” J. Educ. Pract., vol. 7, no. 12, pp. 211-219, 2016

[28] N.S. Rajendran, Teaching \& acquiring higher-order thinking skills: Theory \& practice. Penerbit Universiti Pendidikan Sultan Idris, 2008.

[29] C.C. Chinedu, O.S. Olabiyi, and Y. Kamin, "Strategies for improving higher order thinking skills in teaching and learning of design and technology education," 2015.

[30] N. Nofrion and B. Wijayanto, "Learning Activities in Higher Order Thinking Skill (HOTS) Oriented Learning Context," Geosfera Indones. vol. 3, no. 2, pp. 122-130, 2018

[31] A.R. Saavedra and V.D. Opfer, "Teaching and learning 21st century skills: Lessons from the learning sciences," A Glob. Cities Educ. Netw. Report. New York, Asia Soc., vol. 10, 2012.

[32] R.D. Prayogi, "Kecakapan Abad 21: Kompetensi Digital Pendidik Masa Depan," Manaj. Pendidik., vol. 14, no. 2, 2020

[33] Partnership for 21st Century Skills (P21), Framework for 21st century learning. 2015.

[34] Badan Standar Nasional Pendidikan:BSNP, No Title. 2010

[35] E.Y. Wijaya, D.A. Sudjimat, A. Nyoto, and U.N. Malang, "Transformasi pendidikan abad 21 sebagai tuntutan pengembangan sumber daya manusia di era global," in Prosiding Seminar Nasional Pendidikan Matematika, 2016, vol. 1, no. 26, pp. 263-278

[36] A.J. Nitko and S. M. Brookhart, "Educational Assesment of Student. Englewood Cliffs. NJ: Merrill Prentice Hall.” Inc, 2011.

[37] A. Munandar, E. Maryani, D. Rohmat, and M. Ruhimat, "Establishing the Profesionalism of Geography Teacher through Authentic Assessment Field Study.," Int. J. Instr., vol. 13, no. 2, pp. 797-818, 2020.

[38] L. Darling-Hammond and J. Bransford, Preparing teachers for a changing world: What teachers should learn and be able to do. John Wiley \& Sons, 2007.

[39] S. Asari, R. Husniah, U. Ma'rifah, and K. Anwar, "Fostering Students' High Order Thinking Skills through the Use of Interpretation Cards," Int. J. Educ. Lit. Stud., vol. 7, no. 4, pp. 17-22, 2019.

[40] D. Wiliam, "What is assessment for learning?," Stud. Educ. Eval., vol. 37, no. 1, pp. 3-14, 2011.

[41] M.K. Stein and S. Lane, "Instructional tasks and the development of student capacity to think and reason: An analysis of the relationship between teaching and learning in a reform mathematics project," Educ. Res. Eval., vol. 2, no. 1, pp. 50-80, 1996.

[42] A. Ananda, "Higher-Order Thinking Skills Improvement in Geography Learning on Material of Atmospheric Dynamic," in 1st International Conference on Education Social Sciences and Humanities (ICESSHum 2019), 2019, pp. 947-956.

[43] S.L. Senk, C.E. Beckmann, and D.R. Thompson, "Assessment and grading in high school mathematics classrooms," J. Res. Math. Educ., vol. 28, no. 2, pp. 187-215, 1997.

[44] L. Lewy, Z. Zulkardi, and N. Aisyah, "Pengembangan soal untuk mengukur kemampuan berpikir tingkat tinggi pokok bahasan barisan dan deret bilangan di kelas IX akselerasi SMP Xaverius Maria Palembang,”J. Pendidik. Mat., vol. 3, no. 2, pp. 14-28, 2009.
[45] L.B. Resnick and S.N.R.C. (US). C. on R. in Mathematics, "Education and learning to think," 1987

[46] L.J. Splitter, "Critical thinking: What, why, when and how," Educ Philos. theory, vol. 23, no. 1, pp. 89-109, 1991.

[47] L.W. Anderson and B.S. Bloom, A taxonomy for learning, teaching, and assessing: A revision of Bloom's taxonomy of educational objectives. Longman, 2001.

[48] L.C. Garcia, "Environmental science issues for higher-order thinking skills (HOTS) development: a case study in the Philippines," in Biology Education and Research in a Changing Planet, Springer, 2015, pp. 4554.

[49] A. Aisyah, K. Salehuddin, I. Aman, R.M. Yasin, and N. Mimiko, "Eliciting Elements of Higher Order Thinking Skills in the Higher Secondary Examination Question Structure in Japan and Malaysia," in Proceedings of the Regional Conference on Science, Technology and Social Sciences (RCSTSS 2016), 2019, pp. 455-464.

[50] I.Z. Ichsan, D.V. Sigit, M. Miarsyah, A. Ali, W.P. Arif, and T.A Prayitno, "HOTS-AEP: Higher Order Thinking Skills from Elementary to Master Students in Environmental Learning.," Eur. J. Educ. Res., vol. 8, no. 4, pp. 935-942, 2019

[51] N. Aydin and A. Yilmaz, "The effect of constructivist approach in chemistry education on students higher order cognitive skills," 2010.

[52] D.R. Krathwohl and L.W. Anderson, "Merlin C. Wittrock and the revision of Bloom's taxonomy," Educ. Psychol., vol. 45, no. 1, pp. 64 65, 2010.

[53] P.K. Rao, Sustainable development. (Vol. 1). Blackwell Publishers, 1999.

[54] Sustainable Development Goals (SDGs), "Sustainable Development Goals (SDGs)." www.sdg2030indonesia.org.

[55] UNESCO, UN roadmap for implementing the global action program oneducation for sustainable development. Paris: UN Headquarter, 2015.

[56] E. Hiltunen, "Was it a wild card or just our blindness to gradual change," J. Futur. Stud., vol. 11, no. 2, pp. 61-74, 2006.

[57] M. Ali, "Education Quality Improvement from The Perspective of Sustainable Development Goals Achievement," in Proceeding International Seminar on Education, 2019, vol. 2.

[58] M. Ward, "Education, learning and the 2030 Agenda for Sustainable Development," Organ. Econ. Coop. Dev. OECD Obs., no. 303, p. 11, 2015.

[59] Y.S. Yuniarti, R. Hasan, and M. Ali, "Competencies of Education for Sustainable Development Related to Mathematics Education in Senior High School," in Journal of Physics: Conference Series, 2019, vol. 1179 , no. 1, p. 12075 .

[60] UNESCO, Indonesian National Commission for UNESCO Organizes Strategic Coordination Meeting with the New Minister of Education and Culture. 2014

[61] N.S. Sukmadinata, Metode Penelitian Pendidikan. Bandung: PT. Remaja Rosdakarya, 2009

[62] A.A. Ghani and I. Aziah, "Strengthening Preparedness Education Sustainable Development by the Manager of School Education: A Case Study,” J. Educ. Manag. Leadersh., vol. 17, no. 1, 2007.

[63] H. Mahat, Y. Saleh, M. Hashim, and N. Nayan, "Model development on awareness of education for sustainable schools development in Malaysia," Indones. J. Geogr., vol. 48, no. 1, pp. 37-46, 2016.

[64] P. Copley, "The need to deliver higher-order skills in the context of marketing in SMEs," Ind. High. Educ., vol. 27, no. 6, pp. 465-476, 2013.

[65] R. Lile and C. Bran, "The assessment of learning outcomes," ProcediaSocial Behav. Sci., vol. 163, pp. 125-131, 2014.

[66] F. Saltan and O. F. Divarci, "Using Blogs to Improve Elementary School Students' Environmental Literacy in Science Class.,” Eur. J. Educ. Res., vol. 6 , no. 3, pp. 347-355, 2017. 
[67] T.S. Yen and S.H. Halili, "Effective teaching of higher order thinking (HOT) in education," Online J. Distance Educ. e-Learning, vol. 3, no. 2, pp. 41-47, 2015.

[68] I.N. Rois, "Higher Order Thinking Skill (HOTS) Assessments on Learning English," Proceeding 1 st Conf. English Lang. Lit., 2019.

[69] S. Sajidan and A. Afandi, "Pengembangan Model Pembelajaran Ipa Untuk Memberdayakan Keterampilan Berpikir Tingkat Tinggi," in Prosiding SNPS (Seminar Nasional Pendidikan Sains), 2017, pp. 15-27.

[70] B. Pramesti, S. Sajidan, and S. Dwiastuti, "Stimulating higher-order thinking skills (HOTs) with the module on metabolism topic at the senior high school in Surakarta," in International Conference on Teacher Training and Education 2018 (ICTTE 2018), 2018, pp. 315-318.

[71] C. Lippl, "The Four Cs of 21st Century Skills. Zuluma Education Trends.," 2013. http://zuluma.com/education-trends/four-cs-21stcentury-skills/\#.VLEHY2SUdew.

[72] C. Kivunja, "Exploring the Pedagogical Meaning and Implications of the 4Cs" Super Skills" for the 21st Century through Bruner's 5E Lenses of Knowledge Construction to Improve Pedagogies of the New Learning Paradigm," Creat. Educ., 2015.

[73] R. Germaine, J. Richards, M. Koeller, and C. Schubert-Irastorza, "Purposeful Use of 21st Century Skills in Higher Education.," J. Res. Innov. Teach., vol. 9, no. 1, 2016.

[74] S.M. Danczak, C.D. Thompson, and T.L. Overton, "Development and validation of an instrument to measure undergraduate chemistry students' critical thinking skills," Chem. Educ. Res. Pract., vol. 21, no. 1, pp. 62-78, 2020.

[75] O.L. Liu, L. Frankel, and K.C. Roohr, "Assessing critical thinking in higher education: Current state and directions for next-generation assessment," ETS Res. Rep. Ser., vol. 2014, no. 1, pp. 1-23, 2014.

[76] T. Thonney and J.C. Montgomery, "Defining critical thinking across disciplines: An analysis of community college faculty perspectives," Coll. Teach., vol. 67, no. 3, pp. 169-176, 2019.

[77] M. Sahin and H. Dogantay, "Critical Thinking and Transformative Learning.," Online Submiss., vol. 22, no. 1, pp. 103-114, 2018.

[78] A.S. Keshta and A. Seif, "Evaluating the Higher Order Thinking Skills in Reading Exercises of English for Palestine Grade Eight," Asian J. Educ. E-learning, vol. 1, no. 1, 2013.

[79] N. Hasnunidah, H. Susilo, M. Irawati, and H. Suwono, "The contribution of argumentation and critical thinking skills on students' concept understanding in different learning models," J. Univ. Teach. Learn. Pract., vol. 17, no. 1, p. 6, 2020.

[80] J. Mezirow, "Transformative learning: Theory to practice," New Dir. adult Contin. Educ., vol. 1997, no. 74, pp. 5-12, 1997.

[81] J.L. Wiles PhD, R.E.S. Allen PhD, and R. Butler, "Owning my thoughts was difficult: Encouraging students to read and write critically in a tertiary qualitative research methods course," J. Univ. Teach. Learn. Pract., vol. 13, no. 1, p. 8, 2016.

[82] N.E. Association, Preparing 21st century students for a global society: An educator's guideto the four "Cs." (D. Van Roekel, Ed.). 2012

[83] C. Riegel and A. Kozen, "Attaining 21st Century Skills in a Virtual Classroom.," Educ. Plan., vol. 23, no. 3, pp. 41-55, 2016

[84] P21, "Framework for 21st Century Learning.," Partnership for 21st Century Skills (P21), 2011.

[85] B. Trilling and C. Fadel, 21st Century Skills, Enhanced Edition: Learning for Life in Our Times. John Wiley \& Sons, 2009.

[86] M.D. Kembara, R.W.A. Rozak, and V.A. Hadian, "based Lectures to Improve Students' 4C (Communication, Collaboration, Critical Thinking, and Creativity) Skills," in International Symposium on Social Sciences, Education, and Humanities (ISSEH 2018), 2019, pp. 22-26.

[87] T.J. Shuell, "Cognitive conceptions of learning," Rev. Educ. Res., vol. 56, no. 4, pp. 411-436, 1986.

[88] A.W. Chickering and Z. F. Gamson, "Seven principles for good practice in undergraduate education.," AAHE Bull., vol. 3, p. 7, 1987.
[89] J. Biggs, "What the student does: Teaching for enhanced learning," High. Educ. Res. Dev., vol. 18, no. 1, pp. 57-75, 1999.

[90] J. Hattie, "Teachers Make a Difference, What is the research evidence?," 2003.

[91] W.J. McKeachie, "Good teaching makes a difference-And we know what it is," in The scholarship of teaching and learning in higher education: An evidence-based perspective, Springer, 2007, pp. 457-474.

[92] Y. Ariyana, R. Bestary, and R. Mohandas, "Buku pegangan pembelajaran berorientasi pada keterampilan berpikir tingkat tinggi," Direktorat Jenderal Guru dan Tenaga Kependidikan Kementeri. Pendidik. dan Kebud. Hak, 2018.

[93] A. Kizilaslan, M. Sozbilir, and M.D. Yasar, "Inquiry Based Teaching in Turkey: A Content Analysis of Research Reports.," Int. J. Environ. Sci. Educ., vol. 7, no. 4, pp. 599-617, 2012.

[94] I.G. Margunayasa, N. Dantes, A. Marhaeni, and I. W. Suastra, "The Effect of Guided Inquiry Learning and Cognitive Style on Science Learning Achievement.," Int. J. Instr., vol. 12, no. 1, pp. 737-750, 2019.

[95] Y. Nurrohmi, S. Utaya, and D.H. Utomo, "Pengaruh Model Pembelajaran Discovery Learning Terhadap Kemampuan Berpikir Kritis Mahasiswa," J. Pendidik. Teor. Penelitian, dan Pengemb., vol. 2, no. 10, pp. 1308-1314, 2017.

[96] J.S. Bruner, The process of education. Harvard University Press, 2009.

[97] T.O. Seng, "Thinking skills, creativity, and problem-based learning," Temasek Polytech. Singapore, 2000

[98] C. Vandenhouten, J. Groessl, and E. Levintova, "How do you use problem-based learning to improve interdisciplinary thinking?," New Dir. Teach. Learn., vol. 2017, no. 151, pp. 117-133, 2017.

[99] A. Fajrilia, B. Handoyo, and D. H. Utomo, "Pengaruh Model Problem Based Learning terhadap Kemampuan Berpikir Tingkat Tinggi Siswa SMA,” J. Pendidik. Teor. Penelitian, dan Pengemb., vol. 4, no. 10, pp. 1276-1280, 2019

[100]R.I. Arends, Learning to teach. McGraw-Hill Companies, 2012.

[101]M.-M.P.G. Sumarmi, "Malang.” Aditya Media Publishing, 2012.

[102]B.M. Crowley, "The effects of problem-based learning on mathematics achievement of elementary students across time," 2015.

[103]S.K. Ummah, A. In'am, and R. D. Azmi, "Creating Manipulatives: Improving Students' Creativity through Project-Based Learning.," J. Math. Educ., vol. 10, no. 1, pp. 93-102, 2019.

[104]R.M. Capraro and S. W. Slough, "Why PBL? Why STEM? Why now? An introduction to STEM project-based learning: An integrated science, technology, engineering, and mathematics (STEM) approach," in STEM project-based learning, Brill Sense, 2013, pp. 1-5.

[105]S. Gough, "Rethinking the natural capital metaphor: Implications for education and learning," Environ. Educ. Res., vol. 11, no. 1, pp. 95-114, 2005 .

[106]Y. Liu, Fast multipole boundary element method: theory and applications in engineering. Cambridge university press, 2009.

[107]H. Lateh and P. Muniandy, "Amalan pengajaran pendidikan alam sekitar di Institut Pendidikan Guru, Kampus Pulau Pinang," Geogr. Malaysia J. Soc. Sp., vol. 8, no. 2, p. 1â, 2012.

[108]R. Bolstad, Taking a" future Focus" in Education-what Does it Mean? New Zealand Council for Educational Research, 2011.

[109]P.P. Astutik, "Integrasi Penguatan Pendidikan Karakter (PPK) Dan Higer Order Thinking Skills (HOTS) dalam Pembelajaran Tematik SD," in Seminar Nasional Pendidikan, 2016, vol. 6, no. 2, pp. 65-74

[110]R. Mohamed and O. Lebar, "Authentic assessment in assessing higher order thinking skills," Int. J. Acad. Res. Bus. Soc. Sci., vol. 7, no. 2, pp. 466-476, 2017.

[111]S. M. Brookhart, How to assess higher-order thinking skills in your classroom. ASCD, 2010.

[112]A. Suherman, "Kemampuan Guru Geografi dalam Memahami Paper and Pencil Test Jenis Multiple Choice pada Level Higher Order Thinking Skills (HOTS) Di Kabupaten Bekasi.” Universitas Pendidikan Indonesia, 2019 . 
[113]P. W. Tristananda, "Membumikan Education For Sustainable Development (Esd) di Indonesia dalam Menghadapi Isu-Isu Global," Purwadita J. Agama dan Budaya, vol. 2, no. 2, pp. 42-49, 2018.

[114]P. Valli, P. Perkkilä, and R. Valli, "Adult pre-service teachers applying 21 st century skills in the practice," Athens J. Educ., vol. 1, 2014.

[115]H. Niemi and R. Jakku-Sihvonen, "Teacher education in Finland," Eur. Dimens. Teach. Educ. Similarities Differ., pp. 33-51, 2011.

[116]P. Sahlberg, "Education policies for raising student learning: The Finnish approach,” J. Educ. policy, vol. 22, no. 2, pp. 147-171, 2007.
[117]F. Rokhman, M. Hum, and A. Syaifudin, "Character education for golden generation 2045 (national character building for indonesian golden years)," Procedia-Social Behav. Sci., vol. 141, pp. 1161-1165, 2014.

[118]I. Lampă, A. Greculescu, and L.-L. Todorescu, "Education for sustainable development-Training the young generation for the Future," Procedia-Social Behav. Sci., vol. 78, pp. 120-124, 2013. 